\title{
AN INVERSE CONTROL PROCESS AND AN INVERSE ALLOCATION PROCESS
}

\author{
Seiichi Iwamoto \\ Hiroshima University
}

(Received February 5, 1979; Final July 18, 1980)

\begin{abstract}
An inverse theory of sequential decision processes, including the standard control process and allocation process, is developed. A finite-stage deterministic invertible (main) dynamic program (DP) whose reward functions depend not only on action but also on state is formulated as a sequential decision process. The main DP is transformed into an equivalent inverse DP by an algebraic inversion. The main DP maximizes a generalized total reward, while the inverse DP minimizes a generalized total state. An inverse theorem is established. It characterizes optimal solutions (optimal reward functions and optimal policy) of inverse DP by those of main DP through inverse and composition. The main DP includes a linear equation and quadratic criterion (main) control process on the half-line and a typical multi-stage (main) allocation process. Therefore, the inverse DP generates an inverse control process and an inverse allocation process, respectively. Not solving the recursive equation directly but applying the inverse theorem, optimal solutions of both inverse processes are easily calculated by use of those of the corresponding main processes.
\end{abstract}

\section{Introduction}

Recent1y Iwamoto [5], [6], [7], [8], [9] has developed an inverse theory of dynamic programs which is applicable to a number of mathematical programming problems with a single constraint-function. As will be shown at the concluding remarks, the well-known Iinear equation and quadratic criterion control problem and the multi-stage allocation problem are transformed into equivalent mathematical programming problems with no constraint-function and multiple constraint-functions, respectively. Therefore, the inverse theory is not applicable to control and allocation problems. Furthermore, it makes no doubt that both are most interesting and typical problems which are formulated as sequential decision processes (see Bellman [1, Chap 1], [2, p.116], [3, p.329] and [4, p.10]). These two facts motivate the continuing interests in obtaining a "further" inverse theory for a class of sequential decision processes including control and allocation processes. 
This paper deals with an inversion of finite-stage deterministic dynamic programs ( $D P^{\prime} s$ ) on one-dimensional state space whose $n$-th reward function depends on state and action. These $\mathrm{DP}^{\prime} \mathrm{s}$ are not included in those of [5], [6], [7], [8], [9]. The inverse theory is applied to a linear equation, quadratic criterion and finite-horizon control process on the state space $[0, \infty)$ and to the well-known multi-stage allocation process. This generates two new processes, i.e., an inverse control process and an inverse allocation process. As far as the author knows, both processes have never been discussed elsewhere.

Thus we have established a kind of duality theory for DP's, which is different from Bellman's duality (upper and lower bounds), quasilinearization and inverse problem [2], [4].

In $\$ 2$, specifying seven components, we formulate a (main) DP as a sequential decision process. The recursive formula for the main DP is obtained. In. \$3, for the invertible DP, we specify an inverse DP by the components of the main DP. The recursive formula for the inverse DP is also obtained. This equation is not so we11-known as the usual equations in [1]. In \$4, we establish an inverse theorem between main and inverse DP's. The optimal reward functions of the inverse DP are inverse functions to those of the main DP. The main result is to apply the inverse theorem to a linear equation and quadratic criterion deterministic control process on state space $[0, \infty)$ (in §5) and to a multi-stage allocation process (in \$6). Each process together with its inverse process is solved analytically.

\section{Main dynamic program}

Let $R$ and $S$ be two intervals of one-dimensional Euclidean space $R^{1}$. Then note that if $\mathrm{f}: \mathrm{S} \rightarrow \mathrm{R}$ is onto strictly increasing function, then it is continuous and there exists the inverse function $f^{-1}: R \rightarrow S$ which is onto strictly increasing: Therefore such an $\mathrm{f}$ yields a homeomorphism from $\mathrm{S}$ onto $\mathrm{R}$.

A dynamic program (DP) $D$ is specified by an ordered seven-tuple (Opt, $\left\{\mathrm{S}_{\mathrm{n}}\right\}_{1}^{\mathrm{N}+1},\left\{\mathrm{R}_{\mathrm{n}}\right\}_{1}^{\mathrm{N}+1},\left\{\mathrm{~A}_{\mathrm{n}}\right\}_{1}^{\mathrm{N}},\left\{\mathrm{f}_{\mathrm{n}}\right\}_{1}^{\mathrm{N}}, \mathrm{k},\left\{\mathrm{T}_{\mathrm{n}}\right\}_{1}^{\mathrm{N}}$ ), where

(i) $\mathrm{N}$ is a positive integer, the number of stages.

(ii) $\mathrm{S}_{\mathrm{n}}$ is an interval of $\mathrm{R}^{1}$, the $n$-th state space. This element $\mathrm{s}_{\mathrm{n}}$ is called the $r_{\text {-th }}$ state.

(iii) $R_{n}$ is an interval of $R^{1}$, the $n$-th reward space. This element $r_{n}$ is called the $n$-th reward. 
(iv) $A_{n}$ is a non-empty subset of the $p_{n}$-dimensional Euclidean space $R^{{ }^{p}}{ }$, the $n$-th action space. Further there corresponds for each $\mathrm{n}$-th state $s_{n} \varepsilon s_{n}$ a nonempty subset $A_{n}\left(s_{n}\right)$ of $A_{n}$, the $n$-th action space at state $\mathrm{s}_{\mathrm{n}}$. This element $\mathrm{a}_{\mathrm{n}}$ is called the $n$-th action available at state $\mathrm{s}_{\mathrm{n}}$. We usually write $A_{n}():. S_{n} \rightarrow 2^{A}$, where $2^{A}$ denotes the set of all nonempty subsets of the set $A$. It will be clear from the context whether $A_{n}$ is considered the set or the point-to-set valued mapping. We define the graph of the mapping $A_{n}():. S_{n} \rightarrow 2^{A_{n}}$ by $\operatorname{graph}\left(A_{n}\right)=\left\{\left(s_{n}, a_{n}\right) \mid a_{n} \varepsilon A_{n}\left(s_{n}\right), s_{n} \varepsilon s_{n}\right\} \subset s_{n} \times A_{n} \cdot$

(v) $\mathrm{f}_{\mathrm{n}}: \operatorname{graph}\left(\mathrm{A}_{\mathrm{n}}\right) \times \mathrm{R}_{\mathrm{n}+1} \rightarrow \mathrm{R}_{\mathrm{n}}$ is an onto continuous function such that each $f_{n}\left(s_{n}, a_{n} ; \cdot\right)\left(\left(s_{n}, a_{n}\right) \varepsilon \operatorname{graph}\left(A_{n}\right)\right)$ is strictly increasing, the $n$-th reward function.

(vi) $k: \mathrm{S}_{\mathrm{N}+1} \rightarrow \mathrm{R}_{\mathrm{N}+1}$ is an onto strictly increasing function, the terminal reward function.

(vii) $\mathrm{T}_{\mathrm{n}}: \mathrm{S}_{\mathrm{n}} \times \mathrm{A}_{\mathrm{n}} \rightarrow \mathrm{R}^{1}$ is a continuous function such that its restriction $T_{n} \mid \operatorname{graph}\left(A_{n}\right)$ is a function from $\operatorname{graph}\left(A_{n}\right)$ to $S_{n+1}$ and that each $\mathrm{T}_{\mathrm{n}}\left(\cdot ; \mathrm{a}_{\mathrm{n}}\right)\left(\mathrm{a}_{\mathrm{n}} \in \mathrm{A}_{\mathrm{n}}\right)$ is strictiy increasing, the n-th state transformation.

(viii) Opt is either Max or Min, the optimizer. According as opt $=$ Max or Min, it represents the optimization (maximization or minimization) problem :

$$
\begin{gathered}
\text { Optimize } f_{1}\left(s_{1}, a_{1} ; f_{2}\left(s_{2}, a_{2} ; \ldots ; f_{N}\left(s_{N}, a_{N} ; k\left(s_{N+1}\right)\right) \ldots\right)\right) \\
\text { subject to } \quad \begin{array}{lc}
\text { (i) } T_{n}\left(s_{n} ; a_{n}\right)=s_{n+1} & 1 \leqq n \leqq N \\
\text { (ii) } a_{n} \varepsilon A_{n}\left(s_{n}\right) & 1 \leqq n \leqq N .
\end{array}
\end{gathered}
$$

We call the DP $D$ the main $D P$. Let us now define the $(\mathrm{N}-\mathrm{n}+1)-s u b p r o b z e m$ of $(2.1),(2.2)$ by the problem :

$$
\begin{aligned}
& \text { Optimize } f_{n}\left(s_{n}, a_{n} ; \ldots ; f_{N}\left(s_{N}, a_{N} ; k\left(s_{N+1}\right)\right) \ldots\right) \\
& \text { subject to } \quad \text { (i) } T_{m}\left(s_{m} ; a_{m}\right)=s_{m+1} \quad n \leqq m \leqq N \\
& \text { (ii) } a_{m} \varepsilon A_{m}\left(s_{m}\right) \quad n \leqq m \leqq N,
\end{aligned}
$$

where $s_{n} \varepsilon s_{n}, I \leq n \leq N$. Let $u^{N-n+1}\left(s_{n}\right)$ be the optimum value of $(2.3),(2.4)$. Further we define $u^{0}\left(s_{N+1}\right)$ by

$$
u^{0}\left(s_{N+1}\right)=k\left(s_{N+1}\right) \quad s_{N+1} \varepsilon s_{N+1} .
$$

The function $u^{N-n+1}: s_{n} \rightarrow R_{n}$ is called the $\left(N-n_{1}+1\right)-s t$ optimal reward function 
of $D$. Thus the functions $\left\{u^{0}, u^{1}, \ldots, u^{N}\right\}$ are called the optimal reward functions of $D$. We have the recursive equation between two adjacent optimal reward functions.

Theorem 1. (RECURSIVE FORMULA FOR D)

$$
\begin{aligned}
& u^{N-n+1}\left(s_{n}\right)=0 p t \quad f_{n}\left(s_{n}, a_{n} ; u^{N-n}\left(T_{n}\left(s_{n} ; a_{n}\right)\right)\right) s_{n} \varepsilon s_{n} \text {, } \\
& a_{n} \varepsilon A_{n}\left(s_{n}\right) \quad 1 \leqq n \leqq N \\
& \mathrm{u}^{0}\left(\mathrm{~s}_{\mathrm{N}+1}\right)=\mathrm{k}\left(\mathrm{s}_{\mathrm{N}+1}\right) \quad \mathrm{s}_{\mathrm{N}+1} \in \mathrm{s}_{\mathrm{N}+1}
\end{aligned}
$$

Proof: Easy.

3. Inverse dynamic program

For a two-variable function $\mathrm{h}: \mathrm{A} \times \mathrm{B} \rightarrow \mathrm{C}$ we define two one-variable functions $\mathrm{h}^{\mathrm{a}}: \mathrm{B} \rightarrow \mathrm{C}$ and $\mathrm{h}_{\mathrm{b}}: \mathrm{A} \rightarrow \mathrm{C}$ by

$$
h^{a}(b)=h(a ; b), \quad h_{b}(a)=h(a ; b),
$$

respectively. The main DP $D=\left(\right.$ opt, $\left.\left\{\mathrm{s}_{\mathrm{n}}\right\}_{1}^{\mathrm{N}+1},\left\{\mathrm{R}_{\mathrm{n}}\right\}_{1}^{\mathrm{N}+1},\left\{\mathrm{~A}_{\mathrm{n}}\right\}_{1}^{N},\left\{\mathrm{f}_{\mathrm{n}}\right\}_{1}^{N}, k,\left\{\mathrm{~T}_{\mathrm{n}}\right\}_{1}^{N}\right)$ is called invertible if it has onto strictly increasing optimal reward functions $\left\{u^{0}, u^{1}, \ldots, u^{N}\right\}$. An inverse $D^{-1}$ to the invertible main DP $D$ is specified by the following ordered seven-tuple :

$$
\left.D^{-1}=\overline{(\mathrm{Opt}},\left\{\mathrm{R}_{\mathrm{n}}\right\}_{1}^{\mathrm{N}+1},\left\{\mathrm{~s}_{\mathrm{n}}\right\}_{1}^{\mathrm{N}+1},\left\{\mathrm{~B}_{\mathrm{n}}\right\}_{1}^{\mathrm{N}},\left\{\mathrm{g}_{\mathrm{n}}\right\}^{\mathrm{N}}, l,\left\{\mathrm{U}_{\mathrm{n}}\right\}_{1}^{\mathrm{N}}\right)
$$

where

$$
\begin{aligned}
& \text { (i) } \overline{\mathrm{opt}}=\operatorname{Min} \quad \text { if } \mathrm{Opt}=\operatorname{Max} \\
& =\operatorname{Max} \text { if Opt }=\text { Min }
\end{aligned}
$$

(ii) $\mathrm{B}_{\mathrm{n}}=\mathrm{S}_{\mathrm{n}} \times \mathrm{A}_{\mathrm{n}}$

$$
\begin{aligned}
B_{n}\left(r_{n}\right)=\left\{\left(s_{n}, a_{n}\right) \mid s_{n}=\left(u^{N-n+1}\right)^{-1}\left(r_{n}\right),\right. & a_{n} \varepsilon A_{n}\left(s_{n}\right), \\
& \left.\left(f_{n}\left(s_{n}, a_{n}\right)\right)^{-1}\left(r_{n}\right) \varepsilon R_{n+1}\right\}
\end{aligned}
$$

(iii) $g_{n}\left(a_{n} ; s_{n+1}\right)=\left(T_{n a}\right)^{-1}\left(s_{n+1}\right)$

(iv) $\quad \ell\left(\mathrm{r}_{\mathrm{N}+1}\right)=\mathrm{k}^{-1}\left(\mathrm{~s}_{\mathrm{N}+1}\right)$

(v) $U_{n}\left(r_{n} ; s_{n}, a_{n}\right)=\left(f_{n}\left(s_{n}, a_{n}\right)\right)^{-1}\left(r_{n}\right)$.

We call $D^{-1}$ the inverse $D P$. It represents the problem :

$$
\text { Optimize } g_{1}\left(a_{1} ; g_{2}\left(a_{2} ; \ldots ; g_{N}\left(a_{N} ; \ell\left(r_{N+1}\right)\right) \ldots\right)\right)
$$




$$
\begin{aligned}
& \text { subject to (i) } U_{n}\left(r_{n} ; s_{n} ; a_{n}\right)=r_{n+1} \\
& \text { (ii) }\left(s_{n}, a_{n}\right) \in B_{n}\left(r_{n}\right)
\end{aligned}
$$$$
1 \leqq \mathrm{n} \leqq \mathrm{N}
$$$$
1 \leqq \mathrm{n} \leqq \mathrm{N} \text {. }
$$

Note that the objective function (3.1) does not depend on the sequence of states $\left\{r_{n}\right\}_{1}^{N}$. On the other hand, the $n$-th action at the $n$-th state $r_{n}$ for the inverse DP $D^{-1}$ is formally considered as a direct product $\left(s_{n}, a_{n}\right)$. However, the first action $s_{n}$ has no freedom to be selected. That is, from the definition of $B_{n}\left(r_{n}\right)$, it is uniquely determined by the relation $s_{n}=$ $\left(u^{N-n+1}\right)^{-1}\left(r_{n}\right)$. This notion is not applied to the previous "inverse DP" in [5], [6], [8] and [9]. Only the second action $a_{n}$ is to be controlled so as to optimize (3.1).

We have the following economic interpretations. The main DP $D$ is, given an initial state $s_{1}$, to choose the sequence of actions $\left\{a_{n}\right\}_{1}^{N}$ so as to maximize a generalized total reward $r_{1}$, while the inverse $D P D^{-1}$ is, given an initial reward $r_{1}$, to choose the sequence of actions $\left\{s_{n}, a_{n}\right\}_{1}^{N}$ so as to minimize a generalized total state $s_{1}$. Here state corresponds to cost, manpower, energy, position (in a negative sense), post (in a negative sense), and others. These are compatible with money in a sense. Both the interpretations above for $D$ and $D^{-1}$ follow directly from forward and backward recursive relations

$$
D:\left\{\begin{array}{l}
T_{n}\left(s_{n} ; a_{n}\right)=s_{n+1}, a_{n} \varepsilon A_{n}\left(s_{n}\right) \quad 1 \leqq n \leqq N \\
k\left(s_{N+1}\right)=r_{N+1} \\
f_{n}\left(s_{n}, a_{n} ; r_{n+1}\right)=r_{n} \quad N \geqq n \geqq 1
\end{array}\right.
$$

and

$$
D^{-1}: \begin{cases}U_{n}\left(r_{n} ; s_{n}, a_{n}\right)=r_{n+1},\left(s_{n}, a_{n}\right) \varepsilon B_{n}\left(r_{n}\right) & 1 \leqq n \leqq N \\ \ell\left(r_{N+1}\right)=s_{N+1} & \\ g_{n}\left(a_{n} ; s_{n+1}\right)=s_{n} \quad N \geqq n \geqq 1\end{cases}
$$

respectively, where $\mathrm{N} \geqq \mathrm{n} \geqq 1$ means that the time $\mathrm{n}$ runs backwards $\mathrm{N}+1, \mathrm{~N}$, $\ldots, 2,1$.

The problem (3.1), (3.2) may also be expressed in terms of the components of $D$ as follows :

$$
\begin{aligned}
& \text { Optimize }\left(\mathrm{T}_{1 a_{1}}\right)^{-1 \circ}\left(\mathrm{T}_{2 \mathrm{a}_{2}}\right)^{-1 。} \ldots{ }^{\circ}\left(\mathrm{T}_{\mathrm{Na}}\right)^{-1 \circ_{\mathrm{k}}}{ }^{-1}\left(\mathrm{r}_{\mathrm{N}+1}\right) \\
& \text { subject to (i) } \quad\left(f_{n}\left(s_{n}, a_{n}\right)\right)^{-1}\left(r_{n}\right)=r_{n+1} \quad 1 \leqq n \leqq N \\
& \text { (ii) } a_{n} \varepsilon A_{n}\left(s_{n}\right), \quad s_{n}=\left(u^{N-n+1}\right)^{-1}\left(r_{n}\right) \quad 1 \leqq n \leqq N \\
& \text { (iii) } \quad\left(f_{n}\left(s_{n}, a_{n}\right)\right)^{-1}\left(r_{n}\right) \varepsilon R_{n+1} \quad 1 \leqq n \leqq N \text {. }
\end{aligned}
$$


Similarly, the $(N-n+1)-s u b p r o b l e m$ of $(3.1),(3.2)$ is defined by the problem :

$$
\begin{aligned}
& \text { Optimize } g_{\mathrm{n}}\left(a_{\mathrm{n}} ; \ldots \circ ; \mathrm{g}_{\mathrm{N}}\left(\mathrm{a}_{\mathrm{N}} ; \ell\left(\mathrm{r}_{\mathrm{N}+1}\right)\right) \ldots\right) \\
& \text { subject to } \quad \text { (i) } \mathrm{U}_{\mathrm{m}}\left(\mathrm{r}_{\mathrm{m}} ; \mathrm{s}_{\mathrm{m}}, \mathrm{a}_{\mathrm{m}}\right)=\mathrm{r}_{\mathrm{m}+1} \quad \mathrm{n} \leqq \mathrm{m} \leqq \mathrm{N} \\
& \text { (ii) }\left(\mathrm{s}_{\mathrm{m}}, \mathrm{a}_{\mathrm{m}}\right) \varepsilon \mathrm{B}_{\mathrm{m}}\left(\mathrm{r}_{\mathrm{m}}\right) \quad \mathrm{n} \leqq \mathrm{m} \leqq \mathrm{N},
\end{aligned}
$$

where $r_{n} \varepsilon R_{n}, 1 \leq n \leq N+1$ 。 Let $v^{N-n+1}\left(r_{n}\right)$ be the optimum value of (3.5), (3.6). Further, we define $v^{0}\left(r_{N+1}\right)$ by

$$
v^{0}\left(r_{N+1}\right)=\ell\left(r_{N+1}\right) \quad r_{N+1} \varepsilon R_{N+1} \text {. }
$$

The function $\mathrm{v}^{\mathrm{N}-\mathrm{n}+1}: \mathrm{R}_{\mathrm{n}} \rightarrow \mathrm{S}_{\mathrm{n}}$ is called the $(\mathrm{N}-\mathrm{n}+1)-$ st optimal reward function of $D^{-1}$. Thus the functions $\left\{\mathrm{v}^{0}, \mathrm{v}^{1}, \ldots, \mathrm{v}^{\mathrm{N}}\right\}$ are called the optimal reward functions of $D^{-1}$. The recursive equation becomes as follows :

Theorem 2。 (RECURSTVE FORMULA FOR $D^{-1}$ )

$$
\begin{array}{cl}
v^{N-n+1}\left(r_{n}\right)= & \overline{0 p t} g_{n}\left(a_{n} ; v^{N-n}\left(U_{n}\left(r_{n} ;\left(u^{N-n+1}\right)^{-1}\left(r_{n}\right), a_{n}\right)\right)\right) \\
& a_{n} \varepsilon A_{n}\left(\left(u^{N-n+1}\right)^{-1}\left(r_{n}\right)\right) \\
U_{n}\left(r_{n} ;\left(u^{N-n+1}\right)^{-1}\left(r_{n}\right), a_{n}\right) \varepsilon R_{n+1} & r_{n} \varepsilon R_{n}, \\
v^{0}\left(r_{N+1}\right)=\ell\left(r_{N+1}\right) & r_{N+1} \varepsilon R_{N+1}
\end{array}
$$

Proof: Easy.

\section{Inverse theorem}

In order to state an inverse theorem describing the relationship between the main DP $D$ and the inverse $D P D^{-1}$, let us now define an optimal policy for each DP. A policy of $D$ is a sequence $\left\{\pi_{1}, \pi_{2}, \ldots, \pi_{N}\right\}$ such that the mapping $\pi_{n}: s_{n} \rightarrow A_{n}$ has the property $\pi_{n}\left(s_{n}\right) \varepsilon A_{n}\left(s_{n}\right)$ for $s_{n} \varepsilon s_{n}, 1 \leqq n \leqq N . A$ policy $\left\{\pi_{1}^{*}, \pi_{2}^{*}, \ldots, \pi_{N}^{*}\right\}$ is optimal for $D$ if for each $s_{n} \varepsilon s_{n}, 1 \leqq n \leq N$ $\pi_{n}^{*}\left(s_{n}\right)$ attains the optimum value of $(2.5)$.

On the other hand, a policy of $D^{-1}$ is a sequence $\left\{\sigma_{1}, \sigma_{2}, \ldots, \sigma_{N}\right\}$ such that the mapping $\sigma_{n}: R_{n} \rightarrow A_{n}$ has the property $\sigma_{n}\left(r_{n}\right) \varepsilon A_{n}\left(\left(u^{N-n+1}\right)^{-1}\left(r_{n}\right)\right)$ and $U_{n}\left(r_{n} ;\left(u^{N-n+1}\right)^{-1}\left(r_{n}\right), \sigma_{n}\left(r_{n}\right)\right) \varepsilon R_{n+1}, 1 \leqq n \leqq N$. A policy $\left\{\hat{\sigma}_{1}, \hat{\sigma}_{2}, \ldots\right.$, $\left.\hat{\sigma}_{N}\right\}$ is optimal for $D^{-1}$ if for each $r_{n} \varepsilon R_{n}, 1 \leq n \leq N \quad \hat{\sigma}_{n}\left(r_{n}\right)$ attains the 
Optimum value of $(3.7)$.

Our fundamental result is an inverse theorem in dynamic programming. The differences between the following INVERSE THEOREM and inverse theorems in [5], [6], [8], [9] and [10] are as follows. First, this paper, [5], [9] and [10] discuss sequential decision processes, while [6] and [8] do mathematical programming problems. Second, our theorem treats the case where the objective function is dependent on state sequence, while the others do the case where it is not. Finally, our theorem, as will be shown, is only applicable to control and allocation processes. The others are not. Furthermore both processes have been considered as typical sequential decision processes ([1], [2], [3] and [4]). These are main reasons why we are willing to establish an inverse theory of sequential decision process and apply it to both processes.

Theorem 3. (INVERSE THEOREM) (i) If the main DP $D$ has onto strictly increasing optimal reward functions $\left\{u^{0}, u^{1}, \ldots, u^{N}\right\}$ and an optimal policy $\left\{\pi_{1}^{*}, \pi_{2}^{*}, \ldots, \pi_{N}^{*}\right\}$, then the inverse DP $D^{-1}$ has onto strictly increasing optimal reward functions $\left\{\left(u^{0}\right)^{-1},\left(u^{1}\right)^{-1}, \ldots,\left(u^{N}\right)^{-1}\right\}$ and an optimal policy $\left\{\pi_{1}^{*} \circ\left(u^{N}\right)^{-1}, \pi_{2}^{*} \circ\left(u^{N-1}\right)^{-1}, \ldots, \pi_{N}^{*} \circ\left(u^{1}\right)^{-1}\right\}$.

(ii) Let $\left\{u^{0}, u^{1}, \ldots, u^{N}\right\}$ be onto strictly increasing optimal reward functions of the main $D P D$. If the inverse DP $D^{-1}$ has onto strictly increasing optimal reward functions $\left\{v^{0}, v^{1}, \ldots, v^{N}\right\}$ and an optimal policy $\left\{\hat{\sigma}_{1}, \hat{\sigma}_{2}\right.$, $\left.\cdots, \hat{\sigma}_{N}\right\}$, then it holds that

$$
\left(\mathrm{v}^{\mathrm{N}-\mathrm{n}+1}\right)^{-1}=\mathrm{u}^{\mathrm{N}-\mathrm{n}+1} \quad 1 \leqq \mathrm{n} \leqq \mathrm{N}+1 .
$$

Furthermore, the main DP $D$ has an optimal policy $\left\{\hat{\sigma}_{1}^{\circ}\left(v^{N}\right)^{-1}, \hat{\sigma}_{2}^{\circ}\left(v^{N-1}\right)^{-1}\right.$, $\left.\cdots, \hat{\sigma}_{N}^{\circ}\left(v^{1}\right)^{-1}\right\}$.

Proof: The proof is by induction on $n$. It suffices to prove the theorem only for the case Opt $=$ Max. (i) Let the main DP have onto strictly increasing optimal reward functions $\left\{u^{n}\right\}_{0}^{N}$ and an optimal policy $\left\{\pi_{n}^{*}\right\}_{1}^{N}$. Then we have

$$
\begin{aligned}
u^{N-n+1}\left(s_{n}\right)= & \operatorname{Max} \quad f_{n}\left(s_{n}, a_{n} ; u^{N-n}\left(T_{n}\left(s_{n} ; a_{n}\right)\right)\right) \\
& a_{n} \varepsilon A_{n}\left(s_{n}\right) \\
= & f_{n}\left(s_{n}, \pi_{n}^{*}\left(s_{n}\right) ; u^{N-n}\left(T_{n}\left(s_{n}: \pi_{n}^{*}\left(s_{n}\right)\right)\right)\right) \quad s_{n} \varepsilon s_{n}, \quad 1 \leq n \leq N
\end{aligned}
$$


First, from the definition, we get

$$
v^{0}\left(r_{N+1}\right)=\left(u^{0}\right)^{-1}\left(r_{N+1}\right) \quad r_{N+1} \varepsilon R_{N+1} .
$$

Second, let us consider the case $n=N$ of $(2.5)$. Fix $s_{N} \in s_{N^{*}}$ Let $u^{1}\left(s_{N}\right)=$ $r_{N}, T_{N}\left(s_{N} ; \pi_{N}^{*}\left(s_{N}\right)\right)=s_{N+1}$ and $k\left(s_{N+1}\right)=r_{N+1}$. Then $r_{N} \varepsilon R_{N}$ and $r_{N}=f_{N}\left(s_{N}\right.$, $\left.\pi_{N}^{*}\left(s_{N}\right)\right)\left(r_{N+1}\right)$. Therefore it holds that

$$
\begin{aligned}
s_{N}= & \left(u^{1}\right)^{-1}\left(r_{N}\right) \\
r_{N+1} & =\left(f_{N}\left(s_{N}, \pi_{N}^{*}\left(s_{N}\right)\right)\right)^{-1}\left(r_{N}\right) \\
& =U_{N}\left(r_{N} ; s_{N}, \pi_{N}^{*}\left(s_{N}\right)\right) \\
s_{N} & =\left(T_{N \pi}{ }_{N}^{*}\left(s_{N}\right)\right)^{-1}\left(s_{N+1}\right) \\
= & g_{N}\left(\pi_{N}^{*}\left(s_{N}\right) ; s_{N+1}\right) \\
= & g_{N}\left(\pi_{N}^{*}\left(s_{N}\right) ; l\left(r_{N+1}\right)\right) .
\end{aligned}
$$

Let us define $w^{1}\left(r_{N}\right)$ by

$$
\begin{aligned}
& w^{1}\left(r_{N}\right)= \operatorname{Inf} \quad g_{N}\left(a_{N} ; \ell\left(r_{N+1}\right)\right) \\
&{ }_{N} \varepsilon A_{N}\left(\left(u^{1}\right)^{-1}\left(r_{N}\right)\right) \\
& U_{N}\left(r_{N} ; s_{N}, a_{N}\right)=r_{N+1} \\
& s_{N}=\left(u^{1}\right)^{-1}\left(r_{N}\right)
\end{aligned}
$$

Hence we get $w^{1}\left(r_{N}\right) \leqq s_{N^{*}}$ If $w^{1}\left(r_{N}\right)<s_{N}$, then there exists an $\hat{a}_{N} \varepsilon A_{N}\left(\left(u^{1}\right)-1\right.$ $\left(r_{N}\right)$ ) such that

$$
\mathrm{g}_{\mathrm{N}}\left(\hat{a}_{\mathrm{N}} ; \ell\left(\hat{\mathrm{r}}_{\mathrm{N}+1}\right)\right)<\mathrm{s}_{\mathrm{N}}
$$

where $\hat{r}_{N+1}=U_{N}\left(r_{N} ; s_{N}, \hat{a}_{N}\right), s_{N}=\left(u^{1}\right)^{-1}\left(r_{N}\right)$. Letting $\ell\left(\hat{r}_{N+1}\right)=\hat{s}_{N+1}$, we in turn obtain

$$
\begin{aligned}
& \hat{s}_{N+1}<T_{N}\left(s_{N} ; \hat{a}_{N}\right) \\
& f_{N}\left(s_{N}, \hat{a}_{N} ; \hat{r}_{N+1}\right)=r_{N}
\end{aligned}
$$

and

$$
\text { (4.5) } \quad \mathrm{u}^{1}\left(\mathrm{~s}_{\mathrm{N}}\right)=\mathrm{r}_{\mathrm{N}} \text {. }
$$

Therefore the strict increasingness of $\mathrm{f}_{\mathrm{N}}\left(\mathrm{s}_{\mathrm{N}}, \hat{a}_{\mathrm{N}}:.\right)$ and $\mathrm{k}, \hat{a}_{\mathrm{N}} \varepsilon \mathrm{A}_{\mathrm{N}}\left(\mathrm{s}_{\mathrm{N}}\right)$, and $(4.3),(4.4)$ imply that 


$$
f_{N}\left(s_{N}, \hat{a}_{N} ; k\left(T_{N}\left(s_{N} ; \hat{a}_{N}\right)\right)\right)>r_{N}
$$

This contradicts $(4.5)$. Hence we have $w^{1}\left(r_{N}\right)=s_{N^{*}}$ Since $s_{N} \varepsilon s_{N}$ is arbitrary, we get $w^{1}=\left(u^{1}\right)^{-1}$. This equality together with (4.2) also implies that $\left(u^{1}\right)^{-1}\left(\pi_{N}^{*}\left(s_{N}\right)\right)$ attains the minimum of $(3.7)$ for $n=N$. Finally we get $\mathrm{v}^{1}=\left(\mathrm{u}^{1}\right)^{-1}$

In general, it is inductively shown that

$$
\mathrm{v}^{\mathrm{N}-\mathrm{n}+1}=\left(\mathrm{u}^{\mathrm{N}-\mathrm{n}+1}\right)^{-1} \quad \mathrm{n}=\mathrm{N}-1, \mathrm{~N}-2, \ldots, 1 \text {. }
$$

and that $\left(u^{N-n+1}\right)^{-1}\left(\pi_{n}^{*}\left(s_{n}\right)\right)$ attains the minimum of $(3.7)$ for $n=N-1, N-2$, ... 1. This completes the proof of (i).

(ii) Let the main DP $D$ and the inverse DP $D^{-1}$ have onto strictly increasing optimal reward functions $\left\{\mathrm{u}^{\mathrm{n}}\right\}_{0}^{\mathrm{N}}$ and $\left\{\mathrm{v}^{\mathrm{n}}\right\}_{0}^{\mathrm{N}}$, respectively. Then they satisfy the recursive formulas (2.5), (3.7), respectively. From the analysis in (i), it turns out that the functions $\left\{\left(u^{n}\right)^{-1}\right\}_{0}^{N}$ also satisfy (3.7) and $\left(u^{0}\right)^{-1}=v^{0}$. This implies that $\left(u^{N-n+1}\right)^{-1}=v^{N-n+1}$ namely $\left(v^{N-n+1}\right)^{-1}=u^{N-n+1}$ for $1 \leqq n \leqq N$. The similar argument as in (i) with the roles of $\left\{u^{n}\right\}_{0}^{N}$ and $\left\{v^{n}\right\}_{0}^{N}$ exchanged leads the equality

$$
\begin{aligned}
v^{N-n+1}\left(r_{n}\right)= & \operatorname{Min} g_{n}\left(a_{n} ; v^{N-n}\left(U_{n}\left(r_{n} ;\left(u^{N-n+1}\right)^{-1}\left(r_{n}\right), a_{n}\right)\right)\right) \\
& a_{n} \varepsilon A_{n}\left(\left(u^{N-n+1}\right)^{-1}\left(r_{n}\right)\right) \\
= & g_{n}\left(\hat{\sigma}_{n}\left(r_{n}\right) ; v^{N-n}\left(U_{n}\left(r_{n}:\left(u^{N-n+1}\right)^{-1}\left(r_{n}\right), \hat{\sigma}_{n}\left(r_{n}\right)\right)\right)\right)
\end{aligned}
$$

to the equality

$$
\begin{aligned}
u^{N-n+1}\left(s_{n}\right)= & \operatorname{Max} f_{n}\left(s_{n}, a_{n} ; u^{N-n}\left(T_{n}\left(s_{n} ; a_{n}\right)\right)\right) \\
& a_{n} \varepsilon A_{n}\left(s_{n}\right) \\
= & f_{n}\left(s_{n}, \hat{\sigma}_{n}^{\circ}\left(v^{N-n+1}\right)^{-1}\left(s_{n}\right) ; u^{N-n}\left(T_{n}\left(s_{n} ; \hat{\sigma}_{n}^{\circ}\left(v^{N-n+1}\right)^{-1}\left(s_{n}\right)\right)\right)\right) .
\end{aligned}
$$

Therefore the main DP $D$ has an optimal policy $\left\{\hat{\sigma}_{n}^{\circ}\left(v^{N-n+1}\right)^{-1}\right\}_{1}^{N}$. This completes the proof of (ii).

The INVERSE THEOREM gives us useful informations on one DP, provided that the optimal behavior of the other DP is known. Let $D$ have the desired optimal solutions $\left\{u^{n}\right\},\left\{\pi_{n}^{*}\right\}$. Then the total reward from state $r_{1}$ for $D^{-1}$ is $\left(u^{N}\right)^{-1}\left(r_{1}\right)$. Further, an optimal action at state $r_{n}$ for $D^{-1}$ is $\hat{a}_{n}=\pi_{n}^{*}\left(s_{n}\right)$, where $s_{n}=$ $\left(u^{N-n+1}\right)^{-1}\left(r_{n}\right)$. Conversely, let $D$ and $D^{-1}$ have the desired optimal solutions $\left\{u^{n}\right\},\left\{\pi_{n}^{*}\right\}$ and $\left\{v^{n}\right\},\left\{\hat{\sigma}_{n}\right\}$, respectively. Then $u^{N-n+1}$ is the inverse function of 
$\mathrm{v}^{\mathrm{N}-\mathrm{n}+1}$ and vice versa. Further, an optimal action at state $s_{\mathrm{n}}$ for $D$ is $a_{n}^{*}=\hat{\sigma}_{n}\left(r_{n}\right)$, where $r_{n}=\left(v^{N-n+1}\right)^{-1}\left(s_{n}\right)$, as well as $\hat{a}_{n}=\pi_{n}^{*}\left(s_{n}\right)$.

\section{Inverse control process}

Throughout this section let $\mathrm{b}>0$ and $\mathrm{N}$ be a positive integer. First we consider the following linear equation and quadratic criterion, finite-stage and deterministic control process (see [2, p.116])

$$
\begin{aligned}
& \text { Minimize } \sum_{\mathrm{n}=1}^{\mathrm{N}}\left(\mathrm{x}_{\mathrm{n}}^{2}+\mathrm{y}_{\mathrm{n}}^{2}\right)+\mathrm{x}_{\mathrm{N}+1}^{2} \\
& \text { subject to (i) } b x_{n}+y_{n}=x_{n+1} \quad 1 \leqq n \leq N \\
& \text { (ii) }-\infty<\mathrm{y}_{\mathrm{n}}<-\infty \quad 1 \leqq \mathrm{n} \leqq \mathrm{N}, \quad \mathrm{x}_{1}=\mathrm{c} \text {. }
\end{aligned}
$$

It is well-known that this problem has a quadratic minimum value $\mathrm{u}^{\mathrm{N}}(\mathrm{c})=\mathrm{p}_{\mathrm{N}} \mathrm{c}^{2}$, where $\mathrm{p}_{\mathrm{N}}$ is determined by (5.2) which will be shown later. Note that the function $\mathrm{u}^{\mathrm{N}}:(-\infty, \infty) \rightarrow[0, \infty)$ is not strictly increasing on $(-\infty, 0)$.

Therefore, we further assume the condition $0 \leqq \mathrm{x}_{\mathrm{n}}<\infty$ for $1 \leqq \mathrm{n} \leqq \mathrm{N}$. This restricted problem is written in terms of state $s_{n}$ and action $a_{n}$ as follows :

$$
\begin{gathered}
\text { Minimize } \sum_{n=1}^{N}\left(s_{n}^{2}+a_{n}^{2}\right)+s_{N+1}^{2} \\
\text { subject to } \quad \text { (i) } b_{n}+a_{n}=s_{n+1}, \quad s_{n} \geqq 0 \quad 1 \leqq n \leqq N \\
s_{N+1} \geqq 0 \\
\text { (ii) }-\infty<a_{n}<\infty \quad 1 \leqq n \leqq N, \quad s_{1}=c .
\end{gathered}
$$

Consider a simple inventry model with the following meanings :

$1-b=$ the deterioration rate of the goods, $0 \leqq b<1$

$s_{n}=$ the stock level at the $n$-th period subtracted by constant demand

$a_{n}=$ the production quantity at the $n$-th period.

Then the interpretations for system dynamics and objective function are straightforward.

This problem is represented by an $N$-stage main DP $D=\left(\operatorname{Min},\left\{\mathrm{S}_{n}\right\}_{1}^{N+1},\left\{R_{n}\right\}_{1}^{N+1}\right.$, $\left\{A_{n}\right\}_{1}^{N},\left\{f_{n}\right\}_{1}^{N}, k,\left\{T_{n}\right\}_{1}^{N}$ ), where

$$
\begin{array}{ll}
s_{n}=R_{n}=[0, \infty), & A_{n}=(-\infty, \infty) \\
A_{n}\left(s_{n}\right)=\left[-b s_{n}, \infty\right), & f_{n}\left(s_{n}, a_{n} ; r_{n+1}\right)=s_{n}{ }^{2}+a_{n}{ }^{2}+r_{n+1} \\
k\left(s_{N+1}\right)=s_{N+1}, & T_{n}\left(s_{n} ; a_{n}\right)=b s_{n}+a_{n} .
\end{array}
$$


The main DP $D$ is called the main control process. The corresponding recursive formula

$$
\begin{aligned}
& u^{N-n+1}\left(s_{n}\right)=\operatorname{Min}_{a_{n} \geq-b s_{n}}\left[s_{n}^{2}+a_{n}^{2}+u^{N-n}\left(b s_{n}+a_{N}\right)\right] \quad s_{n} \geqq 0, \quad 1 \leqq n \leqq N \\
& \mathrm{u}^{0}\left(\mathrm{~s}_{\mathrm{N}+1}\right)=\mathrm{s}_{\mathrm{N}+1}{ }^{2} \quad \mathrm{~s}_{\mathrm{N}+1} \geqq 0
\end{aligned}
$$

has quadratic optimal reward functions $\left\{u^{0}, u^{1}, \ldots, u^{N}\right\}$ and a linear optimal policy $\left\{\pi_{1}^{*}, \pi_{2}^{*}, \ldots, \pi_{N}^{*}\right\}$ :

$$
u^{N-n+1}\left(s_{n}\right)=p_{N-n+1} s_{n}^{2}, \quad \pi_{n}^{*}\left(s_{n}\right)=\alpha_{n} s_{n}
$$

where

$$
\begin{aligned}
& \mathrm{p}_{0}=1, \quad \mathrm{p}_{\mathrm{b}}=1+\mathrm{b}^{2}-\frac{\mathrm{b}^{2}}{1+\mathrm{p}_{\mathrm{n}-1}} \quad 1 \leqq \mathrm{n} \leqq \mathrm{N} \\
& \alpha_{\mathrm{n}}=-\frac{\mathrm{p}_{\mathrm{N}-\mathrm{n}}}{1+\mathrm{p}_{\mathrm{N}-\mathrm{n}}} \mathrm{b} \quad \mathrm{I} \leqq \mathrm{n} \leqq \mathrm{N} .
\end{aligned}
$$

Since each $u^{\mathrm{N}-\mathrm{n}+1}:[0, \infty) \rightarrow[0, \infty)$ is onto strictly increasing, the inverse DP $D^{-1}$ is specified by the following components :

$$
\begin{aligned}
& \overline{O p t}=\operatorname{Max}, \quad R_{n}=s_{n}=[0, \infty), \quad B_{n}=[0, \infty) \times(-\infty, \infty) \\
& B_{n}\left(r_{n}\right)=\left\{\left(s_{n}, a_{n}\right) \mid-b s \leq a_{n}, \quad s_{n}=\sqrt{r_{n} / p_{N-n+1}}, \quad s_{n}^{2}+a_{n}^{2} \leq r_{n}\right\} \\
& g_{n}\left(a_{n} ; s_{n+1}\right)=\left(-a_{n}+s_{n+1}\right) / b, \quad \ell\left(r_{N+1}\right)=\sqrt{r}+1 \\
& U_{n}\left(r_{n} ; s_{n}, a_{n}\right)=r_{n}-\left(s_{n}^{2}+a_{n}^{2}\right) .
\end{aligned}
$$

The inverse DP $D^{-1}$ is called the inverse control process. It represents the problem :

$$
\begin{aligned}
& \text { Maximize }-\frac{a_{1}}{b}-\frac{a_{2}}{b^{2}}-\ldots-\frac{a_{N}}{b^{N}}+\frac{\sqrt{r_{N+1}}}{b^{N}} \\
& \text { subject to } \\
& \begin{array}{ll}
\text { (i) } r_{n}-\left(s_{n}^{2}+a_{n}^{2}\right)=r_{n+1} \quad 1 \leqq n \leqq N \\
\text { (ii) } s_{n}=\sqrt{r_{n} / p_{N-n+1}} \quad 1 \leqq n \leqq N \\
\text { (iii) } s_{n}{ }^{2}+a_{n}{ }^{2} \leqq r_{n}, \quad-b s_{n} \leqq a_{n} \quad 1 \leqq n \leqq N .
\end{array}
\end{aligned}
$$

Then the recursive formula becomes as follows :

$$
\begin{array}{rlrl}
v^{N-n+1}\left(r_{n}\right)= & \operatorname{Max}\left[\frac{1}{b}\left(-a_{n}+v^{N-n}\left(r_{n}-s_{n}{ }^{2}-a_{n}{ }^{2}\right)\right)\right] & r_{n} \geqq 0, \\
& s_{n}=\sqrt{r_{n} / p_{N-n+1}} & 1 \leqq n \leqq N \\
& s_{n}{ }^{2}+a_{n}{ }^{2} \leq r \\
& -b s_{n} \leq a_{n} &
\end{array}
$$




$$
\mathrm{v}^{0}\left(\mathrm{r}_{\mathrm{N}+1}\right)=\sqrt{\mathrm{r}_{\mathrm{N}+1}} \quad \mathrm{r}_{\mathrm{N}+1} \geqq 0
$$

However, not solving this equation backwards, but applying the INVERSE THEOREM, we have onto strictly increasing optimal reward functions $\left[v^{0}, v^{1}, \ldots\right.$, $\left.\mathrm{v}^{\mathrm{N}}\right\}$ and an optimal policy $\left\{\hat{\sigma}_{1}, \hat{\sigma}_{2}, \ldots, \hat{\sigma}_{\mathrm{N}}\right\}$ :

$$
\begin{aligned}
& v^{N-n+1}\left(r_{n}\right)=\left(u^{N-n+1}\right)^{-1}\left(r_{n}\right)=\sqrt{r_{n} / p_{N-n+1}} \\
& \hat{\sigma}_{n}\left(r_{n}\right)=\pi_{n}^{*}{ }^{\circ}\left(u^{N-n+1}\right)^{-1}\left(r_{n}\right)=\left(\alpha_{n} / \sqrt{p_{N-n+1}}\right) \sqrt{r_{n}} .
\end{aligned}
$$

of course these optimal solutions are obtained by solving directly the recursive equation (5.3). The reader will find that solving (5.3) is more difficult than (5.1). Therefore the application of the INVERSE THEOREM is more effective than solving (5.3).

In particular, two-stage main control process $D$ and its inverse control process $D^{-1}$ have

$$
\begin{aligned}
& u^{0}\left(s_{3}\right)=s_{3}^{2} \\
& u^{1}\left(s_{2}\right)=\left(s+\frac{1}{2} b^{2}\right) s_{2}^{2} \quad \pi_{2}^{*}\left(s_{2}\right)=-\frac{1}{2} b s_{2} \\
& u^{2}\left(s_{1}\right)=\frac{2+\frac{3}{2} b^{2}+\frac{1}{2} b^{4}}{2+\frac{1}{2} b^{2}} s_{1}^{2} \quad \pi_{1}^{*}\left(s_{1}\right)=-\frac{b\left(1+\frac{1}{2} b^{2}\right)}{2+\frac{1}{2} b^{2}} s_{1}
\end{aligned}
$$

and

$$
\begin{array}{ll}
\mathrm{v}^{0}\left(\mathrm{r}_{3}\right)=\sqrt{\mathrm{r}_{3}} & \mathrm{v}^{1}\left(\mathrm{r}_{2}\right)=\frac{1}{\sqrt{1+\frac{1}{2} b^{2}} \sqrt{\mathrm{r}_{2}}} \quad \hat{\sigma}_{2}\left(\mathrm{r}_{2}\right)=\frac{-\frac{1}{2} b}{\sqrt{1+\frac{1}{2} b^{2}} \sqrt{r_{2}}} \\
v^{2}\left(r_{1}\right)=\frac{\sqrt{2+\frac{1}{2} b^{2}}}{\sqrt{2+\frac{3}{2} b^{2}+\frac{1}{2} b^{4}}} \sqrt{r_{1}} \quad \hat{\sigma}_{1}\left(r_{1}\right)=\frac{-b\left(1+\frac{1}{2} b^{2}\right)}{\sqrt{\left(2+\frac{1}{2} b^{2}\right)\left(2+\frac{3}{2} b^{2}+\frac{1}{2} b^{4}\right)}} \sqrt{r_{1}},
\end{array}
$$

respectively.

\section{Inverse allocation process}

Throughout this section let $0 \leqq a<1,0<b<1, c_{1}, c_{2}, c_{3}, d>0$ and $N$ be a positive integer. Consider the following typical N-stage allocation 
problem (see $[1, \mathrm{p} .44])$ :

$$
\begin{aligned}
& \text { Maximize } \sum_{n=1}^{N}\left[c_{1} a_{n}^{d}+c_{2}\left(s_{n}-a_{n}\right) d^{d}+c_{3} s_{N+1} d\right. \\
& \text { subject to } \quad \text { (i) } a_{n}+b\left(s_{n}-a_{n}\right)=s_{n+1} \quad 1 \leqq n \leqq N \\
& \text { (ii) } 0 \leqq a_{n} \leqq s_{n} \quad 1 \leqq n \leqq N .
\end{aligned}
$$

The economic interpretation is stated in [1, p.4]. This problem is represented by an $\mathrm{N}$-stage main DP $D$ whose components are specified as follows :

$$
\begin{aligned}
& \overline{O p t}=\operatorname{Max}, s_{n}=R_{n}=A_{n}=[0, \infty) \quad A_{n}\left(s_{n}\right)=\left[0, s_{n}\right] \\
& f_{n}\left(s_{n}, a_{n} ; r_{n+1}\right)=c_{1} a_{n}+c_{2}\left(s_{n}-a_{n}\right)+r_{n+1} \\
& k\left(s_{N+1}\right)=c_{3} s_{N+1} d, \quad T_{n}\left(s_{n} ; a_{n}\right)=a a_{n}+b\left(s_{n}-a_{n}\right) .
\end{aligned}
$$

We call $D$ the main allocation process. It is easily shown that the main allocation process $D$ has onto strictly increasing optimal reward functions $\left\{\mathrm{u}^{0}\right.$, $\left.\mathrm{u}^{1}, \ldots, \mathrm{u}^{\mathrm{N}}\right\}$ and an optimal policy $\left\{\pi_{1}^{*}, \pi_{2}^{*}, \ldots, \pi_{\mathrm{N}}^{*}\right\}$ :

$$
u^{N-n+1}\left(s_{n}\right)=p_{N-n+1} s_{n}^{d}, \quad \pi_{n}^{*}\left(s_{n}\right)=\alpha_{n} s_{n}
$$

where

$$
\mathrm{p}_{0}=\mathrm{c}_{3}
$$

(6.1) $\quad \mathrm{p}_{\mathrm{N}-\mathrm{n}+1}=\underset{0 \leq \mathrm{Max} \leq 1}{=}\left[c_{1} \mathrm{x}^{\mathrm{d}}+\mathrm{c}_{2}(1-\mathrm{x})^{\mathrm{d}}+\mathrm{p}_{\mathrm{N}-\mathrm{n}}(\mathrm{ax}+\mathrm{b}(1-\mathrm{x}))^{\mathrm{d}}\right] \quad 1 \leqq \mathrm{n} \leq \mathrm{N}$

and $\alpha_{n}$ is the value of $x$ which attains the maximum of (6.1).

On the other hand, the components of the inverse DP $D^{-1}$, called the inverse allocation process, become as follows :

$$
\begin{aligned}
& \overline{\text { Opt }}=\text { Min, } s_{n}=R_{n}=[0, \infty), \quad B_{n}=[0, \infty) \times[0, \infty) \\
& B_{n}\left(r_{n}\right)=\left\{\left(s_{n}, a_{n}\right) \mid 0 \leq a_{n} \leq s_{n}=\left(r_{n} / p_{N-n+1}\right)^{1 / d}, c_{1} a_{n} d+c_{2}\left(s_{n}-a_{n}\right)^{d} \leq r_{n}\right\} \\
& g_{n}\left(a_{n} ; s_{n+1}\right)=\left(-(a-b) a_{n}+s_{n+1}\right) / b, \quad l\left(r_{N+1}\right)=\left(r_{N+1} / c_{3}\right)^{1 / d} \\
& U_{n}\left(r_{n} ; s_{n}, a_{n}\right)=r_{n}-c_{1} a_{n}^{d}-c_{2}\left(s_{n}-a_{n}\right)^{d} .
\end{aligned}
$$

The inverse allocation process $D^{-1}$ represents the problem :

$$
\begin{aligned}
& \text { Minimize }-\frac{a-b}{b} a_{1}-\frac{a-b}{b^{2}} a_{2}-\ldots-\frac{a-b}{b^{N}} a_{N}+\frac{1}{b^{N}}\left(\frac{{ }^{n}+1}{c_{3}}\right)^{1 / d} \\
& \text { subject to (i) } r_{n}-c_{1} a_{n}^{d}-c_{2}\left(s_{n}-a_{n}\right)^{d}=r_{n+1} \quad 1 \leqq n \leqq N
\end{aligned}
$$




$$
\begin{aligned}
& \text { (ii) } s_{n}=\left(\frac{r_{n}}{p_{N-n+1}}\right) 1 / d \quad 1 \leqq n \leqq N \\
& \text { (iii) } 0 \leqq a_{n} \leqq s_{n}, \quad c_{1} a_{n}^{d}+c_{2}\left(s_{n}-a_{n}\right) d \leqq r_{n} \quad 1 \leqq n \leqq N .
\end{aligned}
$$

The corresponding recursive formula becomes

$$
\begin{aligned}
& \text { (6.2) } v^{N-n+1}\left(r_{n}\right)=\quad \operatorname{Min}_{\#}\left[\frac{1}{b}\left(-(a-b) a_{n}+v^{N-n}\left(r_{n}-c_{1} a_{n}{ }^{d}-c_{2}\left(s_{n}-a_{n}\right) d\right)\right)\right] \\
& \mathrm{r}_{\mathrm{n}} \geqq 0, \quad 1 \leqq \mathrm{n} \leqq \mathrm{N} \\
& \#:=\left\{\begin{array}{l}
s_{n}=\left(r_{n} / p_{N-n+1}\right)^{1 / d} \\
c_{1} a_{n}{ }^{d}+c_{2}\left(s_{n}-a_{n}\right)^{d} \leq n \\
0 \leq a_{n} \leq s_{n}
\end{array}\right. \\
& v^{0}\left(r_{N+1}\right)=\left(r_{N+1} / c_{3}\right)^{1 / d} \quad r_{N+1} \geqq 0
\end{aligned}
$$

The INVERSE THEOREM gives the inverse allocation process $D^{-1}$ and the following optimal solutions :

$$
\begin{aligned}
& v^{N-n+1}\left(r_{n}\right)=\left(u^{N-n+1}\right)^{-1}\left(r_{n}\right)=\left(r_{n} / p_{N-n+1}\right)^{1 / d} \\
& \hat{\sigma}_{n}\left(r_{n}\right)=\pi_{n}^{*} \circ\left(u^{N-n+1}\right)^{-1}\left(r_{n}\right)=\left(\alpha_{n} /\left(\left(p_{N-n+1}\right)^{1 / d}\right) r_{n}{ }^{1 / d} .\right.
\end{aligned}
$$

Note that the recursive equation $(6.2)$ has the solution

$$
v^{N-n+1}\left(r_{n}\right)=q_{N-n+1} r_{n}^{1 / d}, \quad \hat{\sigma}_{n}\left(r_{n}\right)=\beta_{n} r_{n}^{1 / d}
$$

where

$$
\mathrm{q}_{0}=1 /\left(\mathrm{c}_{3}^{1 / \mathrm{d}}\right)
$$

$$
\begin{aligned}
& \mathrm{q}_{\mathrm{N}-\mathrm{n}+1}=\quad \text { Min } \quad\left[-\frac{(\mathrm{a}-\mathrm{b})}{\mathrm{b}} \mathrm{y}+\frac{1}{\mathrm{~b}} \mathrm{q}_{\mathrm{N}-\mathrm{n}}\left(1-\mathrm{c}_{1} \mathrm{y}^{\mathrm{d}}-\mathrm{c}_{2}\left(\left(\frac{1}{\mathrm{p}_{\mathrm{N}-\mathrm{n}+1}}\right)^{1 / d}-\mathrm{y}\right)^{\mathrm{d}}\right)^{1 / d}\right] \\
& 0 \leq \mathrm{y} \leqq\left(\frac{1}{\mathrm{p}_{\mathrm{N}-\mathrm{n}+1}}\right)^{1 / \mathrm{d}} \\
& c_{1} y+c_{2}\left(\left(\frac{1}{p_{N-n+1}}\right)^{1 / d}-y\right) \leqq 1
\end{aligned}
$$

and $\beta_{n}$ is the value of $y$ which attains the minimum of $(6.3)$. Thus we obtain

$$
\mathrm{q}_{\mathrm{N}-\mathrm{n}+1}=1 /\left(\left(\mathrm{p}_{\mathrm{N}-\mathrm{n}+1}\right)^{1 / \mathrm{d}}\right), \quad \beta_{\mathrm{n}}=\alpha_{\mathrm{n}} /\left(\left(\mathrm{p}_{\mathrm{N}-\mathrm{n}+1}\right)^{1 / \mathrm{d}}\right) .
$$

In particular, for the case $a=0$ and $d=1 / 2$, we have 


$$
\begin{array}{ll}
\mathrm{p}_{0}=\mathrm{c}_{3} & \\
\mathrm{p}_{\mathrm{N}-\mathrm{n}+1}=\mathrm{c}_{1}^{2}+\left(\mathrm{c}_{2}+\sqrt{\mathrm{b} \mathrm{p}_{\mathrm{N}-\mathrm{n}}}\right)^{2} & 1 \leqq \mathrm{n} \leqq \mathrm{N} \\
\alpha_{\mathrm{n}}=\frac{\mathrm{c}_{1}^{2}}{\mathrm{c}_{1}^{2}+\left(\mathrm{c}_{2}+\sqrt{\mathrm{b} \mathrm{p}_{\mathrm{N}-\mathrm{n}}}\right)^{2}} & 1 \leqq \mathrm{n} \leqq \mathrm{N}
\end{array}
$$

and

$$
\begin{aligned}
& \mathrm{q}_{0}=\frac{1}{\mathrm{c}_{3}{ }^{2}} \\
& \mathrm{q}_{\mathrm{N}-\mathrm{n}+1}=\frac{1}{\mathrm{c}_{1}{ }^{2}+\left(\mathrm{c}_{2}+\sqrt{\mathrm{b}} / \sqrt{\mathrm{q}_{\mathrm{N}-\mathrm{n}}}\right)^{2}} \quad 1 \leqq \mathrm{n} \leqq \mathrm{N} \\
& \beta_{n}=\frac{c_{1}{ }^{2}}{c_{1}{ }^{2}+\left(c_{2}+\sqrt{b} / \sqrt{q_{N-n}}\right)^{2}}\left(\frac{1}{p_{N-n+1}}\right)^{2} \quad 1 \leqq n \leqq N,
\end{aligned}
$$

respective1y.

Concluding remarks

Eliminating the state variables $s_{2}, s_{3}, \ldots, s_{N+1}$, and identifying $s_{1}, a_{1}, a_{2}, \ldots, a_{N}$ with $c, x_{1}, x_{2}, \ldots, x_{N}$ we transform the problem represented by the main control process in $\$ 5$ into an equivalent constrained mathematical programming problem :

$$
\begin{aligned}
& \text { Minimize } \quad\left(b^{N} c+b^{N-1} x_{1}+\ldots+b x_{N-1}+x_{N}\right)^{2} \\
& +\left(b^{\mathrm{N}-1} \mathrm{c}+\mathrm{b}^{\mathrm{N}-2} \mathrm{x}_{1}+\ldots+\mathrm{bx}_{\mathrm{N}-2}+\mathrm{x}_{\mathrm{N}-1}\right)^{2}+\mathrm{x}_{\mathrm{N}-1}^{2} \\
& +\left(b^{N-2} c+b^{N-3} x_{1}+\ldots+b_{N-3}+x_{N-2}\right)^{2}+x_{N-2}^{2} \\
& \vdots \\
& +\left(b c+x_{1}\right)^{2}+x_{1}^{2} \\
& \text { subject to } \\
& \text { (1) } \mathrm{b}^{\mathrm{N}} \mathrm{c}+\mathrm{b}^{\mathrm{N}-1} \mathrm{x}_{1}+\ldots+\mathrm{bx}_{\mathrm{N}-1}+\mathrm{x}_{\mathrm{N}} \geqq 0 \\
& \text { (2) } \mathrm{b}^{\mathrm{N}-1} \mathrm{c}+\mathrm{b}^{\mathrm{N}-2} \mathrm{x}_{1}+\ldots+\mathrm{bx}_{\mathrm{N}-2}+\mathrm{x}_{\mathrm{N}-1} \geqq 0 \\
& : \\
& \text { (N) } \mathrm{bc}+\mathrm{x}_{1} \geq 0 \\
& (N+1) \quad-\infty<x_{i}<\infty \\
& I \leqq I \leqq N
\end{aligned}
$$


where positive constant $b$ is given and parameter $c$ ranges on half 1 ine $[0, \infty)$. Thus we have the following one-parametric, quadratic and multi-constrained problem :

$$
\begin{gathered}
\text { Minimize }(x, A(c) x)+2(b(c), x)+d(c) \\
\text { subject to }(i) \quad B(c) x \geq e(c) \\
\text { (ii) } x \in R^{N},
\end{gathered}
$$

where $A(c)$ is positive definite and $B(c)$ is upper-triangular and nonsingular. Note that the original control process without nonnegativity of state variables represents the equivalent unconditional problem without constraint (i). Simi1arly, the main allocation process in $\$ 6$ represents an equivalent, one-parametric, and multi-constrained problem. These problems leave us an open problem of developing a general inverse theory for parametric multi-constrained mathematical programing problems.

The inverse theory has generated a counterpart in dynamic programming problem whose solution is obtained through inverse and composition from the solution of the original dynamic programming problem. Furthermore, the theory generates a new class of dynamic programming problems whose solution is not charactized by the solution of the original porblem. These problems are obtained from the inverse problem by exchanging the constraints $s_{n}=\left(u^{N-n+1}\right)^{-1}$ $\left(r_{n}\right) \quad 1 \leq n \leq N$ for another constraints.

Finally we remark that with appropriate modifications the preceding argument will remain valid for a number of sequential decision processes on the onedimensional state space.

Acknowledgement

The author would like to express his hearty thanks to anonymous referees whose helpful suggestions and valuable comments have improved the manuscript.

\section{Reference}

[1] Bellman, R.: Dynamic Programming. Princeton University Press, New Jersey, 1957.

[2] Bellman, R.: Introduction to the Mathematical Theory of Control Processes. Vol. I, Linear Equations and Quadratic Criteria. Academic Press, New York, 1967.

[3] Bellman, R.: Introduction to Matrix Analysis. 2nd Ed. McGraw-Hill, New York, 1970. 
[4] Bellman, R.: Introduction to the Mathematical Theory of Control Processes. Vol. II, Nonlinear Processes。 Academic Press, New York, 1971.

[5] Iwamoto, S.: Inverse Dynamic Programming. Memoirs of the Faculty of Science. Kyushu University. Series A. Mathematics. Vo1. 30, No. 1 (1976), 24-42.

[6] Iwamoto, S.: Inverse Theorem in Dynamic Programming I. Journal of Mathematical Analysis and Applications. Vo1. 58, No. 1(1977), 113-134.

[7] Iwamoto, S.: Inverse Theorem in Dynamic Programming II. Journal of Mathematical Analysis and Applications. Vo1. 58, No. 2(1977), 247-279.

[8] Iwamoto, S.: Inverse Theorem in Dynamic Programming III. Journal of Mathematical Analysis and Applications. Vo1. 58, No. 3(1977), 439-448.

[9] Iwamoto, S.: Inverse Dynamic Programming II. Memoirs of the Faculty of Science. Kyushu University. Series A. Mathematics. Vo1. 31, No. 1 (1977), 24-44.

[10] Iwamoto, S.: An Inverse Theorem Between Main and Inverse Dynamic Programming : Infinite-Stage Case. Dynamic Progromming and Its Applications; Proceedings of the International Conference on Dynamic Programming (ed. M. L. Puterman). Academic Press, New York, 1978, 319-334.

Seiichi IWAMOTO: Study of Information and Behavioral Sciences, Faculty of Integrated Arts and Sciences, Hiroshima University, Hiroshima, 730, Japan. 
逆制御過程と逆配分過程

広島大学岩本誠一

まず，逐次決定過程として定式化された一次元状態空間上の有限段確定的動的計画（主動的計画） の逆（逆動的計画）を定義し，両計画に対して数理計画の双対定理に対応する定理（逆定理）を導い ている。つぎに，この考え方をいわゆる制御過程（主制御過程）・多段配分過程（主配分過程）に応 用して，それぞれ逆制御過程・逆配分過程を導入している。逆定理を適用すると，逆過程の最適解 (最適利得関数列と最適政策) は，直按再帰式を解くことなく，主過程の最適解の逆関数演算と合成 関数演算によって簡単に求められる。事実, 逆過程の再帰式を解くことは主過程より相当困難である。 このような意味です逆定理は有効である。

说来の逆定理に扣いては，その主動的計画の目的関数は

$$
f_{1}\left(a_{1} ; f_{2}\left(a_{2} ; \cdots ; f_{N}\left(a_{N} ; k\left(s_{N+1}\right)\right) \cdots\right)\right)
$$

であった。ここで $\mathrm{a}_{\mathrm{n}}$ は第n段に扣ける決定である。このため, 応用範囲が一制約式の数理計画問題に に限定されていた。本論文では，目的関数を状態列 $\left\{s_{1}, s_{2}, \cdots \cdots, s_{N+1}\right\}$ にも依存する再帰 型関数

$$
\mathrm{f}_{1}\left(\mathrm{~s}_{1}, \mathrm{a}_{1} \mathrm{f}_{2}\left(\mathrm{~s}_{2}, \mathrm{a}_{2} ; \ldots ; \mathrm{f}_{\mathrm{N}}\left(\mathrm{s}_{\mathrm{N}}, \mathrm{a}_{\mathrm{N}} ; \mathrm{k}\left(\mathrm{s}_{\mathrm{N}+1}\right)\right) \cdots\right)\right.
$$

にしても，いわゆる逆理論が展開できることがわかった。このような目的関数は一般の逐次決定過程 によく現われる。本論文の逆定理はこれらの過程に適用可能である。特に, 制御過程・配分過程につ いてその逆過程を中心に解析している。

考方方の本質的な点は，(1)主動的計画に打ける状態と決定との対をその状態に拈ける“新しい決定” と見做して，(2)本来の状態を最適利得関数列に沿って逆変換したものとそのときの決定との対を，逆 動的計画に打忛る“新しい決定”として（3)従来の逆定理の考方方を部分的に尊入したことにある。 